\title{
Effects of Cations/Anions in Recycled Tailing Water on Cationic Reverse Flotation of Iron Oxides
}

\author{
Min Tang and Shuming Wen * \\ State Key Lab of Complex Nonferrous Metal Resources Clean Utilization, Faculty of Land and Resource \\ Engineering, Kunming University of Science and Technology, Kunming 650093, China; \\ mtang-kmust@foxmail.com \\ * Correspondence: shumwen@126.com
}

Received: 14 December 2018; Accepted: 3 March 2019; Published: 7 March 2019

\begin{abstract}
It is well known that reverse flotation performance of iron oxides is affected by water quality. Since many potential variations among water sources recycling in a mineral processing plant bring unpredictable effects on the flotation system of iron oxides: disturbing ions/compounds, $\mathrm{pH}$, hardness, residual reagents, etc. In this study, the recycled tailing water from a local plant, characteristically constituting of $\mathrm{Ca}^{2+}, \mathrm{Mg}^{2+}, \mathrm{Na}^{+}, \mathrm{K}^{+}, \mathrm{Al}^{3+}, \mathrm{Fe}^{3+}, \mathrm{Cl}^{-}, \mathrm{SO}_{4}{ }^{2-}$ etc., was introduced into the cationic reverse flotation process of an iron ore. A series of bench flotation tests using iron ores, micro-flotation tests using pure fine quartz, water chemical analyses, and zeta potential measurement were conducted with the objective of identifying the possible influences of both cations and anions in the recycled tailing water on the flotation performance. The flotation results pointed out that the cation with higher valency had more severe influences on the recovery of iron oxides. The formation of the $\mathrm{pH}$-dependent surface complexes on mineral surfaces, for example, $\mathrm{Fe}(\mathrm{OH})^{+}$, $\mathrm{Fe}(\mathrm{OH})^{2+}$, and $\mathrm{Fe}(\mathrm{OH})_{3}$ resulted from $\mathrm{Fe}^{3+}$ ions adsorption, contributed to the less negative zeta potentials of the quartz, and consequently weakened its interaction with the amine collector. It is worthy to note that $\mathrm{SO}_{4}{ }^{2-}$ ions seem to have a more positive effect on the recovery of iron oxides than $\mathrm{Cl}^{-}$ions. This is probably attributed to the formation of inner/outer- sphere surface complexes on the iron oxides, inhibiting the dissolution of the iron ions/species, and the coordination with these cations from the recycled tailing water, shielding their disturbances in the flotation.
\end{abstract}

Keywords: cations; anions; tailing water; recycling; iron oxide; cationic reverse flotation

\section{Introduction}

It is essential for a mineral processing plant to reduce plant-operating costs and minimize impact on the local ecosystem by increasing water reuse. The recycled water is usually enriched with many dissolved ions/compounds [1-3]. And a gradual built-up of some dissolved cations/anions such as $\mathrm{K}^{+}, \mathrm{Na}^{+}, \mathrm{Ca}^{2+}, \mathrm{Mg}^{2+}, \mathrm{Fe}^{3+}, \mathrm{Al}^{3+}, \mathrm{Cl}^{-}, \mathrm{No}_{3}{ }^{-}, \mathrm{SO}_{4}{ }^{2-}$ etc., possibly occurs during water recycling in a flotation process. This could bring an unexpected change into the physicochemical/electrochemical atmosphere of flotation pulp, affecting mineral floatability as well as dewatering and pumping [3].

Table 1 shows the positive or negative effects of ions, especially cations, $\mathrm{Ca}^{2+}, \mathrm{Mg}^{2+}, \mathrm{Fe}^{3+}, \mathrm{Al}^{3+}, \mathrm{K}^{+}$, $\mathrm{Na}^{+}$etc., in the reverse/direct flotation of iron oxides [4-13]. It seems to be complicated to figure out specific effects of these cations on the effectiveness of flotation since they may be detrimental in some cases $[5,11,13]$, while in other cases they may be beneficial to the flotation process $[4,7-10,12]$. But it is closely related to the properties of minerals floated, type of flotation reagents, especially collector, and valence/concentration of cations as well. Since the promotive effects of these cations mainly occur in the anionic reverse flotation of iron oxides [4,7-10] while the competitive effects of them obviously take place in the cationic reverse flotation or anionic direct flotation $[5,11,13]$. And either promotive or 
competitive effects of these cations in the flotation of iron oxides largely depend on their valences and concentrations based on the data from Table $1[4,7,9,12,13]$.

Table 1. Some literature about the effects of cations/anions in the water on the reverse/direct flotation of iron oxides [4-13].

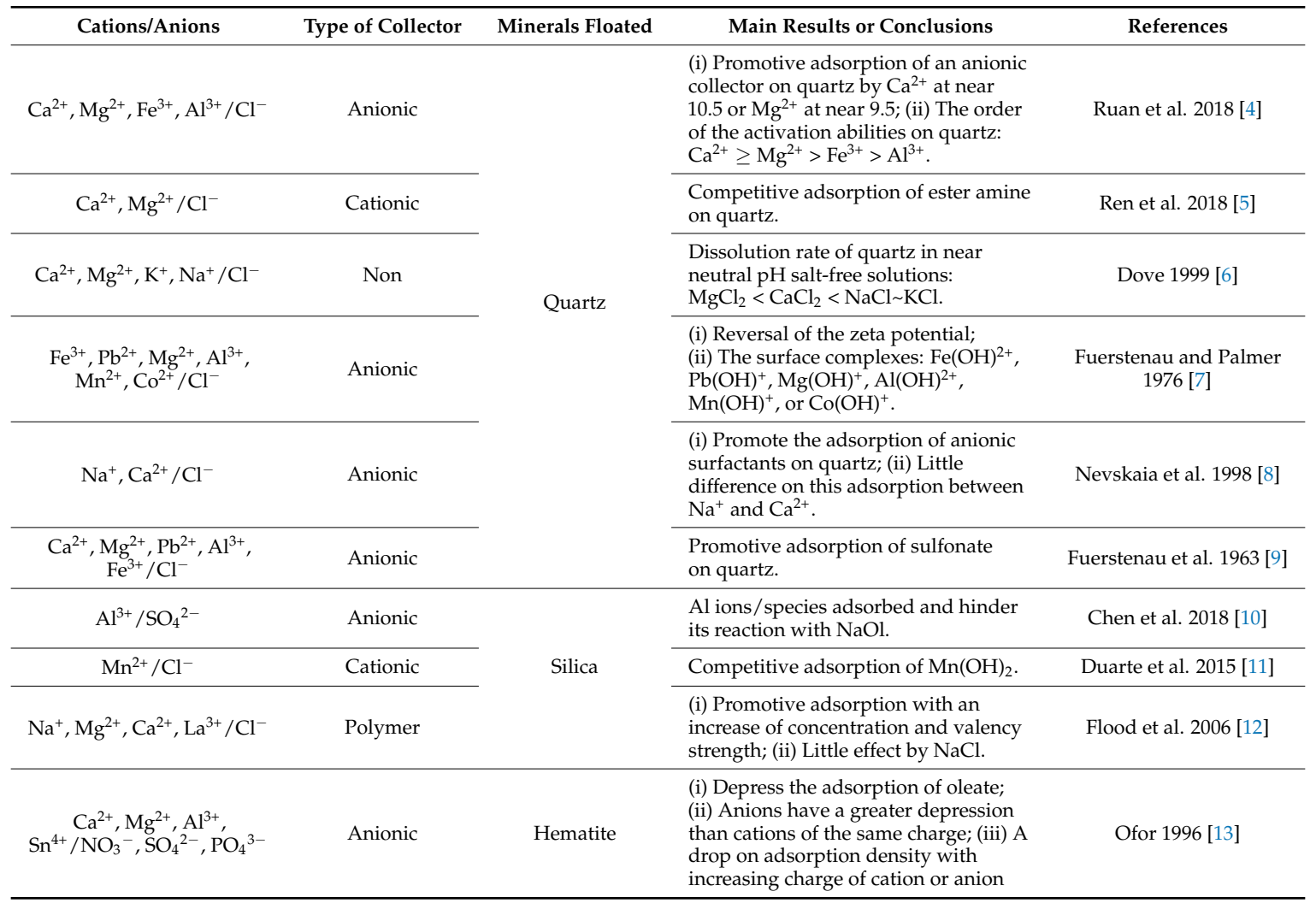

There are a few reports focusing on the influences of the metal ions in flotation by their valences and concentrations. Flood et al. (2006) reported that the adsorption of Poly(ethylene oxide) on the silica can be enhanced with the metal ions at a higher valence or concentration [12]. Identical observations have been made by Choi et al. (2016), indicating that $\mathrm{Ca}^{2+}$ or $\mathrm{Mg}^{2+}$ ions have a more promotive effect on the adsorption of sodium oleate on malachite than $\mathrm{K}^{+}$or $\mathrm{Na}^{+}$ions at the same concentration [14]. Ofor (1996) and Wang et al. (2019) also found that the metal ions with a higher valence tend to have a more depressive effect in the anionic flotation of molybdenite or hematite [13,15]. But Ruan et al. (2018) reported that the activation abilities on the quartz of the divalent cations $\left(\mathrm{Ca}^{2+} \mathrm{Or} \mathrm{Mg}^{2+}\right)$ are greater than the trivalent cations $\left(\mathrm{Fe}^{3+}\right.$ or $\left.\mathrm{Al}^{3+}\right)$ during the anionic flotation [4].

A change or even reversal of the zeta potential resulted from the adsorption of cations/their compounds on mineral surfaces probably contributes to their promotive or competitive effects in flotation [7,9,16-18]. According to the previous research performed by Fuerstenau and Palmer (1976), $\mathrm{Ca}^{2+}$ or $\mathrm{Mg}^{2+}$ ions at a high concentration induce a reversal of the surface charge on the silica from negative to positive and hinder the adsorption of the amine collector on the mineral surfaces [7].

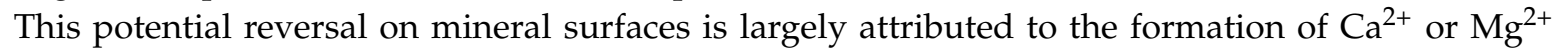
hydrolyzed products, such as $\mathrm{Ca}(\mathrm{OH})^{+}, \mathrm{CaCO}_{3}, \mathrm{Mg}(\mathrm{OH})^{+}, \mathrm{Mg}(\mathrm{OH})_{2}, \mathrm{MgCO}_{3}$ etc. [16]. The findings by Rao (2004) also show that the potential reversal hinders the floatability of the minerals if collector adsorption dominantly depends on electrostatic interaction [17]. This is well in agreement with the observations made by Ren et al. (2018), indicating that $\mathrm{Ca}^{2+}$ ions reverse the zeta potential of the quartz by physical adsorption and inhibit the adsorption of an ester mine on it [5]. In addition, Shortridge et al. (1999) found that the presence of ions such as $\mathrm{Mg}^{2+}$ and $\mathrm{Ca}^{2+}$ ions in the flotation system can enhance the depressive activity of the CMC polymer due to its strong negative charge density [18]. 
Only a couple of studies placed emphasis on the role of anions in plant water. Ofor (1996) found that an anion in water has a greater depression than a cation at the same charge in the flotation of hematite, and an increase in the valence of anion leads to a drop on the adsorption of oleate on hematite [13]. Ikumapayi and Rao (2015) also reported that the presence of $\mathrm{SO}_{4}{ }^{2-}$ ions influence the recovery of the chalcopyrite and galena due to the competitive adsorption between $\mathrm{CaCO}_{3}$ and $\mathrm{PbSO}_{4}[19]$.

Although the role of some cations, for example, $\mathrm{Fe}^{3+}, \mathrm{Al}^{3+}, \mathrm{Ca}^{2+}, \mathrm{Mg}^{2+}, \mathrm{K}^{+}$or $\mathrm{Na}^{+}$ions in water during anionic reverse flotation of iron oxides is well established, the possible effects of those cations, and the typical anion, $\mathrm{Cl}^{-}$or $\mathrm{SO}_{4}{ }^{2-}$ ions, on cationic reverse flotation of iron oxides are not sufficiently understood. In this study, the influences of the cation, $\mathrm{Fe}^{3+}, \mathrm{Al}^{3+}, \mathrm{Ca}^{2+}, \mathrm{Mg}^{2+}, \mathrm{K}^{+}$or $\mathrm{Na}^{+}$, and anion, $\mathrm{Cl}^{-}$or $\mathrm{SO}_{4}{ }^{2-}$ from the recycled tailing water on the cationic reverse flotation performance of iron oxides were investigated. A series of micro-flotation tests using pure fine quartz, bench flotation tests using an iron ore fed in the field, water chemical analyses, and zeta potential measurement were also conducted with the objective of identifying how the cations/anions in the water influence the cationic reverse flotation system of the iron oxides was also made.

\section{Materials and Methods}

\subsection{Materials}

An iron oxide ore sample was collected and sampled from an iron mine in Yunnan, China. It was at a size range of about $87.6 \%$ passing 74 microns. The ore contains $55.6 \% \mathrm{Fe}, 10.5 \% \mathrm{SiO}_{2}, 1.89 \% \mathrm{CaO}$, $3.28 \% \mathrm{MgO}, 1.36 \% \mathrm{Al}_{2} \mathrm{O}_{3}$. The main iron oxides are magnetite, accounting for $67 \%$. And part of them is associated with the silica gangues. The main gangues containing silica are quartz, talc, chlorite etc. Several barrels of the recycled tailing water sample were collected, sealed and transported from the local tailing ponds, about $25 \mathrm{~km}$ from the local concentrator in Yunnan, China. The removal of the slimes and residues of the organic reagents from the tailing water sample were also conducted before water chemical analyses and flotation tests. The pure quartz and all reagents used for zeta potential measurement and flotation tests were shown in Table 2.

Table 2. The materials and reagents used in this study.

\begin{tabular}{ccc}
\hline Materials or Reagents & Serial Number/Company & Purity, \% \\
\hline Corn starch & S-4180/Sigma-Aldrich, St. Louis, MO, USA & 99.0 \\
DDA & 124-22-1/Shandong Chemical Technology Co., Laizhou, China & $/{ }^{\circ} \mathrm{C} 155.0 \sim 158.0(2.0)$ \\
Sodium hydroxide & S318-1/Thermo Fisher Scientific, Shanghai, China & 98.8 \\
Sodium chloride & S271-500/Thermo Fisher Scientific, Shanghai, China & 99.8 \\
Calcium chloride & 10043-52-4/Kunming Minerals Co., Kunming, China & 96 \\
Magnesium chloride & 7791-18-6/Kunming Minerals Co., Kunming, China & 99 \\
Ferric chloride & 10025-77-1/Kunming Minerals Co., Kunming, China & 99 \\
Aluminum chloride & 446-70-0/Kunming Minerals Co., Kunming, China & $\geq 98.5$ \\
Sodium sulfate & 7757-82-6/Sigma-Aldrich, St. Louis, MO, USA & $\geq 99.0$ \\
Hydrochloric acid & 7647-01-0/Thermo Fisher Scientific, Shanghai, China & $36.5-38.0$ \\
Sulfuric acid & 7664-93-9 Sigma-Aldrich, MO, USA & $95-98$ \\
Quartz $(-37 \mu \mathrm{m}, 90 \%)$ & Kunming Minerals Co., Kunming, China & 95.0 \\
\hline
\end{tabular}

DDA, Dodecylamine.

\subsection{Methods}

\subsubsection{Bench Flotation Tests}

To prepare the sample to do bench flotation tests, $500 \mathrm{~g}$ of the iron ore sample was weighted and mixed with tap water at room temperature. The flotation test was conducted by using a $1.5 \mathrm{~L}$ cell (XF-D) for roughing and cleaning stages at an impeller speed of $1200 \mathrm{rpm}$ for a certain time based on the flowsheet shown in Figure 1a. A froth depth $(\mathrm{FH})$ of $15.2 \mathrm{~cm}$, superficial gas velocity $\left(\mathrm{J}_{\mathrm{g}}\right)$ of $0.75 \mathrm{~cm} / \mathrm{s}$ and collecting time $(\mathrm{t})$ of $10 \mathrm{~min}$ was employed for the roughing stage, but a froth depth 
of $11.5 \mathrm{~cm}$ and collecting time of $4 \mathrm{~min}$ at the same superficial gas velocity for the cleaning stage. Dodecylamine (DDA) as a collector, caustic-digested corn starch as flocculants, and sodium hydroxide or hydrochloric acid as $\mathrm{pH}$ modifiers were introduced in the test. It was conducted at a natural $\mathrm{pH}$ (near $9.0( \pm 0.3)$ ) for using tap water, or at a similar $\mathrm{pH}$ range adjusted by hydrochloride acid for using recycled tailing water. The concentrate, middling, and tailing from the bench flotation tests had been filtrated, dried, weighted, and then assayed the grade of $\mathrm{Fe}$ and $\mathrm{SiO}_{2}$, respectively. Each result plotted to the curve was chosen directly from a series of five repeating tests, which was a highly repeatable one. The error bars covered the total range of these values instead of the standard deviation.

A five-day closed-circuit flotation test was performed in the local plant using the recycled tailing water as shown in Figure 1b. It employed the same flotation reagents as the ones shown in Figure 1a. Hydrochloride acid was used in the close-circuit as a pH modifier. The cumulative content of the main cations/anions in the flotation process water of the feed, concentrate, and tailing were also analyzed after settling, centrifuging, and filtrating.

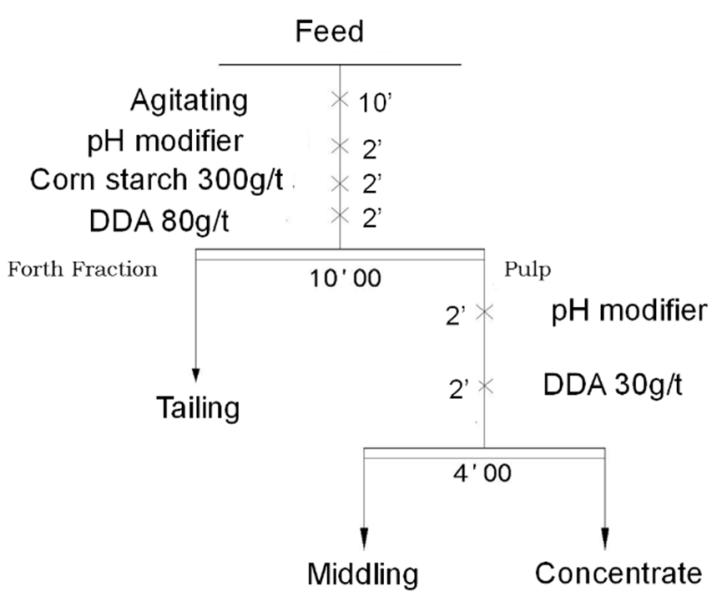

(a) Open-circuit

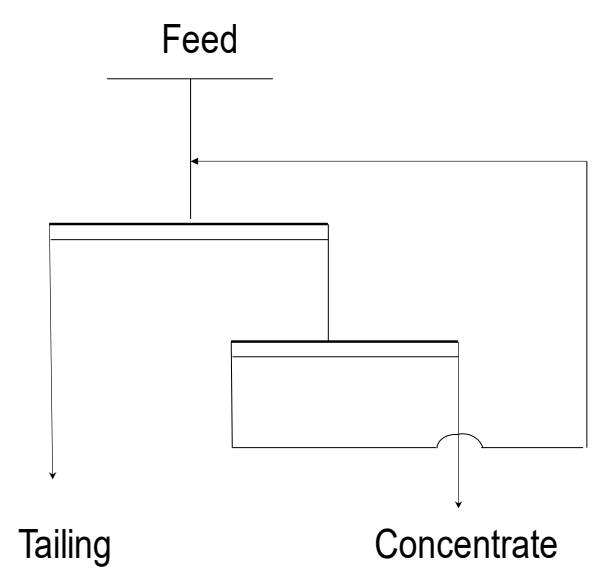

(b) Close-circuit

Figure 1. The open/closed-circuit flowsheet of the reverse cationic flotation of the iron ores in Yunnan, China: (a) Open-circuit, (b) Close-circuit.

\subsubsection{Micro-Flotation Tests}

To prepare the sample for a flotation test using a Hallimond cell, a $1 \mathrm{~g}$ quartz was weighed and mixed with $100 \mathrm{~mL}$ of distilled water. A $10 \mathrm{mg} / \mathrm{L}$ DDA as a collector was used for each test and its conditioning time was $1 \mathrm{~min}$. Calcium chloride, magnesium chloride, aluminum chloride, or ferric chloride at a concentration of $1 \mathrm{mmol} / \mathrm{L}$ was added and conditioned for $5 \mathrm{~min}$ if needed before the addition of the collector. All micro-flotation tests were performed at an air rate of $0.2 \mathrm{~m}^{3} / \mathrm{min}$ at room temperature, and the flotation time was $1 \mathrm{~min}$.

\subsubsection{Zeta Potential Measurement}

The zeta potentials of quartz were measured with the use of a ZetaPALS zeta potential and particle size analyzer manufactured by Brookhaven Instruments Corporation, Holtsville, NY, USA. The technique is based on electrophoretic light scattering (ELS), also known as Laser Doppler Velocimetry (LDV). To prepare samples for the zeta potential measurements, a $100 \mathrm{~mL} 0.5 \%(5 \mathrm{~g} / \mathrm{L})$ quartz solution was mixed with $100 \mathrm{~mL}$ of a metal ion at a different concentration at room temperature. The mixed suspension was stirred at room temperature for $10 \mathrm{~min}$. Five $\mathrm{mL}$ of the mixed suspension was withdrawn and diluted to $100 \mathrm{~mL}$ with a $10^{-3} \mathrm{~mol} / \mathrm{L} \mathrm{NaCl}$ solution. The $\mathrm{pH}$ of the diluted suspension was adjusted using $\mathrm{HCl}$ or $\mathrm{NaOH}$, and a small aliquot of the suspension was transferred to the sample cell of the ZetaPALS for zeta potential measurements. 


\subsubsection{Water Chemical Analyses}

The contents of the metal ions in the recycled tailing water sample were analyzed by an ICP-AES instrument purchased from Thermo Fisher Scientific, Shanghai, China, while the contents of $\mathrm{Cl}^{-}$and $\mathrm{SO}_{4}{ }^{2-}$ ions, and total hardness in the water sample were detected by titration in terms of standards.

\section{Results and Discussion}

\subsection{Water Chemistry of the Recycled Tailing Water and Its Reuse in Flotation}

\subsubsection{Effect on Flotation Performance by Using the Recycled Tailing Water}

Figure 2 presents the comparison on the grade/recovery of $\mathrm{Fe}$ and content of $\mathrm{SiO}_{2}$ in concentrates as a function of \% recycling tailing water reported into the flotation system at a $\mathrm{pH}$ range of 8.5-9.3. The data showed that there is an upward trend on the recovery of $\mathrm{Fe}$ and content of $\mathrm{SiO}_{2}$ with increasing \% recycling tailing water. An increase by $1.5 \%$ on the content of $\mathrm{SiO}_{2}$ and $6.0 \%$ on the recovery of $\mathrm{Fe}$ in the concentrate by using the recycled tailing water only occurs in comparison by using the fresh tap water only. It seems to be beneficial to improve the recovery of Fe in concentrates by using the recycled tailing water, but at a cost of the quality of concentrates by dramatically increasing the content of $\mathrm{SiO}_{2}$ and lowering the grade of $\mathrm{Fe}$. The disturbing inorganic ions, especially cations in the recycled tailing water may play an important role in influencing the interactions between DDA and silica by modifying the surface zeta potential of the minerals [1-8,14-17].

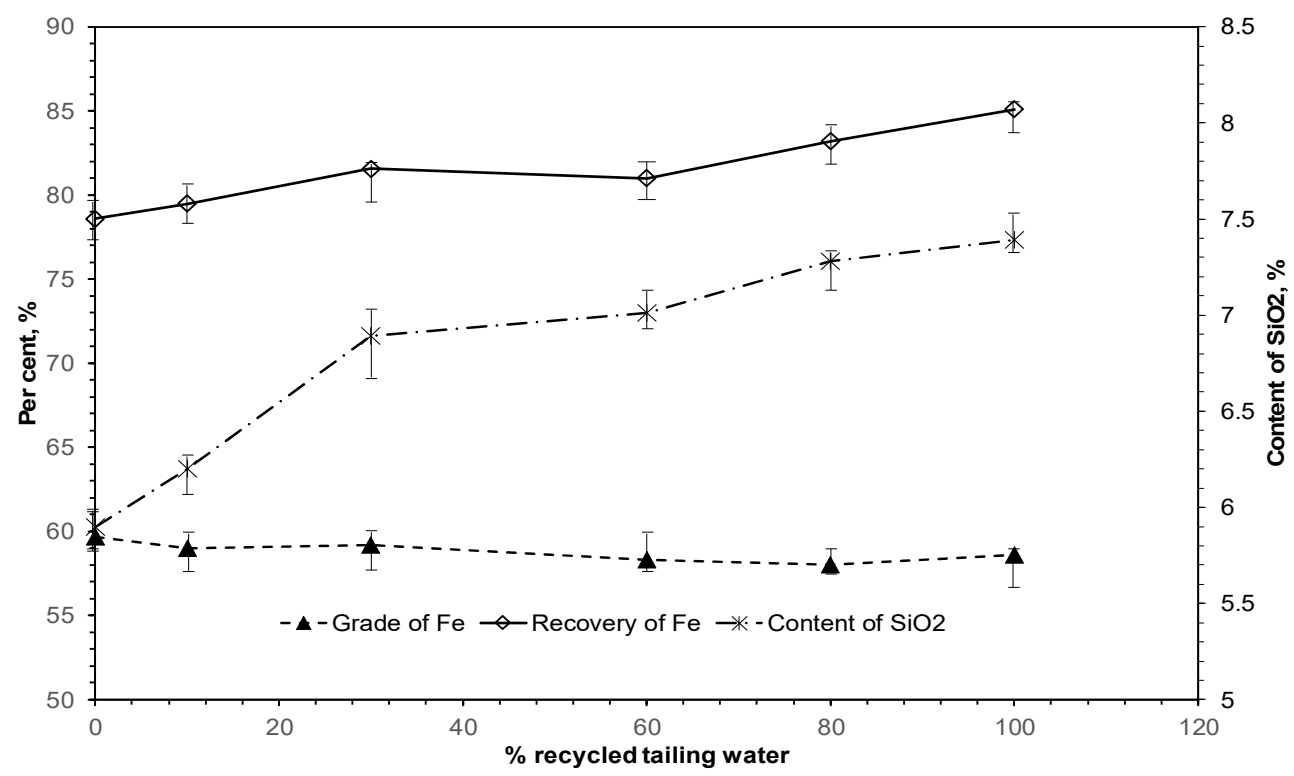

Figure 2. The effects on the grade/recovery of $\mathrm{Fe}$ and content of $\mathrm{SiO}_{2}$ in concentrate as a function of \% recycling tailing water.

\subsubsection{Water Chemistry of the Recycled Tailing Water}

The main elements in the recycled tailing water before/after entering the flotation process and tap water from the lab were shown in Table 3. The content of the main cations, $\mathrm{Al}^{3+}, \mathrm{TFe}^{\mathrm{n}+}, \mathrm{Ca}^{2+}$ and $\mathrm{Mg}^{2+}$ ions, as well as the dominant anions, $\mathrm{Cl}^{-}$and $\mathrm{SO}_{4}{ }^{2-}$ ions in the tailing water before entering into the flotation system was obviously much higher than the one in the tap water. The total hardness of the recycled tailing water was approximately 10 times the hardness of the tap water. The comparison of the accumulative content of the main cations/anions in concentrates/tailings after a five-day closed-circuit process by using the recycled tailing water alone was also provided from Table 3 . It indicates that the accumulative rates of the content of $\mathrm{Ca}^{2+}, \mathrm{Mg}^{2+}$, and total hardness in the tailing water were much higher than in the concentrate water. But the built-up on the contents of $\mathrm{TFe}^{\mathrm{n}+}, \mathrm{Cl}^{-}$, and $\mathrm{SO}_{4}{ }^{2-}$ ions is 
the opposite, which is distinctly faster in the water from the concentrate than from the tailing. A sharp increase on the recovery of $\mathrm{Fe}$ and content of $\mathrm{SiO}_{2}$ in the concentrate from the flotation tests using the recycled tailing water as shown in Figure 2 may be closely related to the built-up of these ions, especially the cations, either in the tailing or concentrate. Since these cations/their species could adsorb on the surface of the silica, modifying the zeta potential and triggering the disfunction of the amine collector on the minerals [14-19].

Table 3. Chemical analysis of the tap water in the lab and recycled tailing water before/after its reuse in the flotation process.

\begin{tabular}{|c|c|c|c|c|}
\hline \multirow[b]{2}{*}{ Item } & \multirow{2}{*}{$\begin{array}{l}\text { Tap Water } \\
\text { from Lab }\end{array}$} & \multirow{2}{*}{$\begin{array}{l}\text { Recycled Tailing Water } \\
\text { before Its Reuse }\end{array}$} & \multicolumn{2}{|c|}{ Recycled Tailing Water after Its Reuse } \\
\hline & & & $\begin{array}{l}\text { Water Filtrated } \\
\text { from Concentrate }\end{array}$ & $\begin{array}{l}\text { Water Filtrated } \\
\text { from Tailing }\end{array}$ \\
\hline $\mathrm{pH}$ & 7.90 & 9.80 & 9.90 & 9.50 \\
\hline $\mathrm{Al}^{3+}, \mathrm{mg} / \mathrm{L}$ & $<0.020$ & 0.035 & 0.020 & 0.038 \\
\hline $\mathrm{TFe}^{\mathrm{n}+}, \mathrm{mg} / \mathrm{L}$ & 0.009 & 5.361 & 16.12 & 8.57 \\
\hline $\mathrm{Ca}^{2+}, \mathrm{mg} / \mathrm{L}$ & - & 196.5 & 278.3 & 235.4 \\
\hline $\mathrm{Mg}^{2+}, \mathrm{mg} / \mathrm{L}$ & - & 134.7 & 186.9 & 268.9 \\
\hline $\begin{array}{l}\text { Total Hardness } \\
\left(\mathrm{CaCO}_{3}\right), \mathrm{mg} / \mathrm{L}\end{array}$ & 158.7 & 1254 & 1587 & 1871 \\
\hline $\mathrm{Cl}^{-}, \mathrm{mg} / \mathrm{L}$ & 5.52 & 258 & 589 & 347 \\
\hline $\mathrm{SO}_{4}{ }^{2-}, \mathrm{mg} / \mathrm{L}$ & 12.7 & 463 & 972 & 417 \\
\hline
\end{tabular}

\subsection{Flotation Performance of Iron Oxides in the Presence of Cations}

As shown in Figure $3 \mathrm{a}-\mathrm{c}$, the recovery/grade of $\mathrm{Fe}$ and content of $\mathrm{SiO}_{2}$ in the concentrate change a little if $\mathrm{Na}^{+}$or $\mathrm{K}^{+}$ions are present in the tap water. But the multivalent cation, especially $\mathrm{Al}^{3+}$ or $\mathrm{Fe}^{3+}$ ions, has a significant influence on the flotation performance. The results show that there is a substantial downward trend on the grade of $\mathrm{Fe}$ and an obvious upward trend on the content of $\mathrm{SiO}_{2}$ with increasing concentration of $\mathrm{Al}^{3+}$ or $\mathrm{Fe}^{3+}$ ions in the tap water. An increase by approximately $6.0 \%$ on the recovery of $\mathrm{Fe}$, but at a cost of a drop by near $2.5 \%$ on the grade of $\mathrm{Fe}$, and an increase by $3.7 \%$ on the content of $\mathrm{SiO}_{2}$ occurs if the concentration of $\mathrm{Al}^{3+}$ ions reached $800 \mathrm{mg} / \mathrm{L}$. A different story was observed in the presence of $\mathrm{Ca}^{2+}$ or $\mathrm{Mg}^{2+}$ ions. High concentration of $\mathrm{Mg}^{2+}$ only induces a slight increase in the recovery of iron with a little change on the grade of iron and content of $\mathrm{SiO}_{2}$. But it seems to be beneficial to upgrade the concentrate in the presence of $\mathrm{Ca}^{2+}$ ions because an upward trend on the grade of iron was observed with increasing its concentration. This is inconsistent with the previous research $[7,12]$, indicating that floatability of silica has little change in the presence of sodium chloride, while the promotive adsorption of an anionic collector on quartz can be harvested by increasing the concentration and valency of cation [7-10,12]. In terms of the accumulative content of the main cations as shown in Table 3, an obvious build-up of $\mathrm{TFe}^{\mathrm{n}+}, \mathrm{Ca}^{2+}$ or $\mathrm{Mg}^{2+}$ ions either in the concentrate or tailing water after the closed-circuit flotation test occurs, which may contribute to the increase in the content of $\mathrm{SiO}_{2}$ and the drop in the grade of Fe in concentrates from Figure 2. 


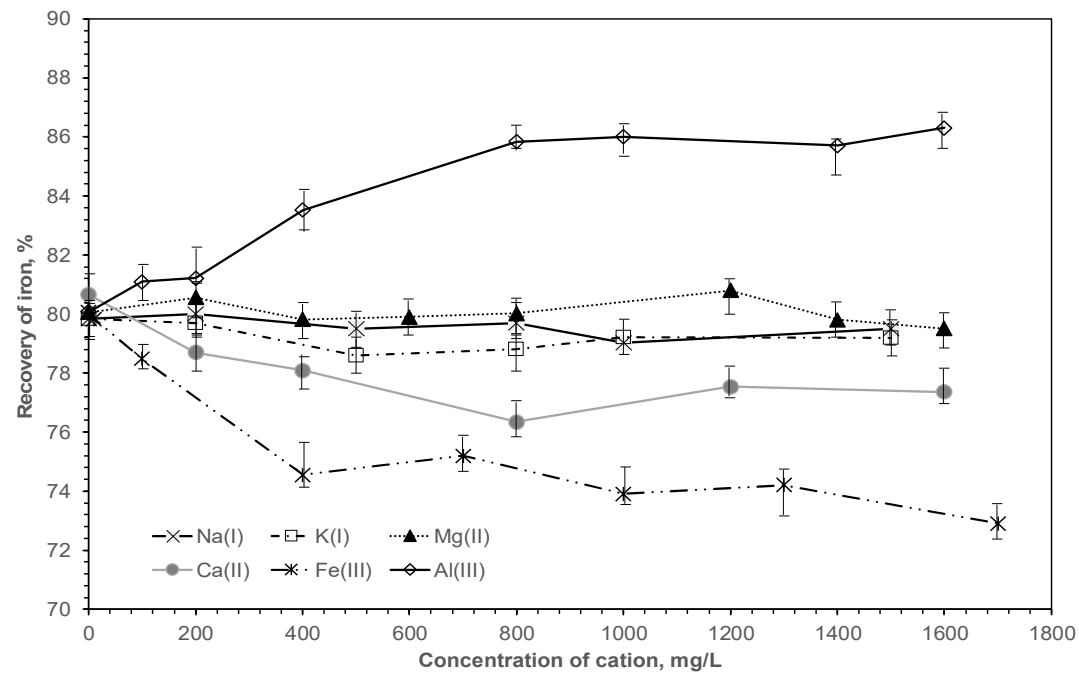

(a)

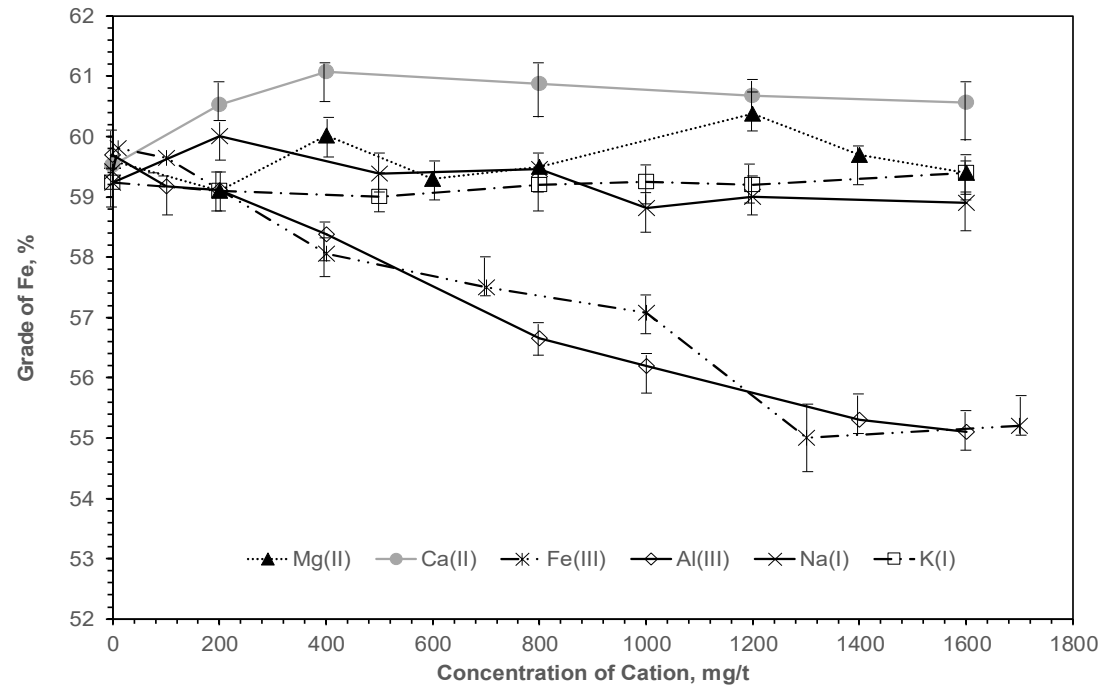

(b)

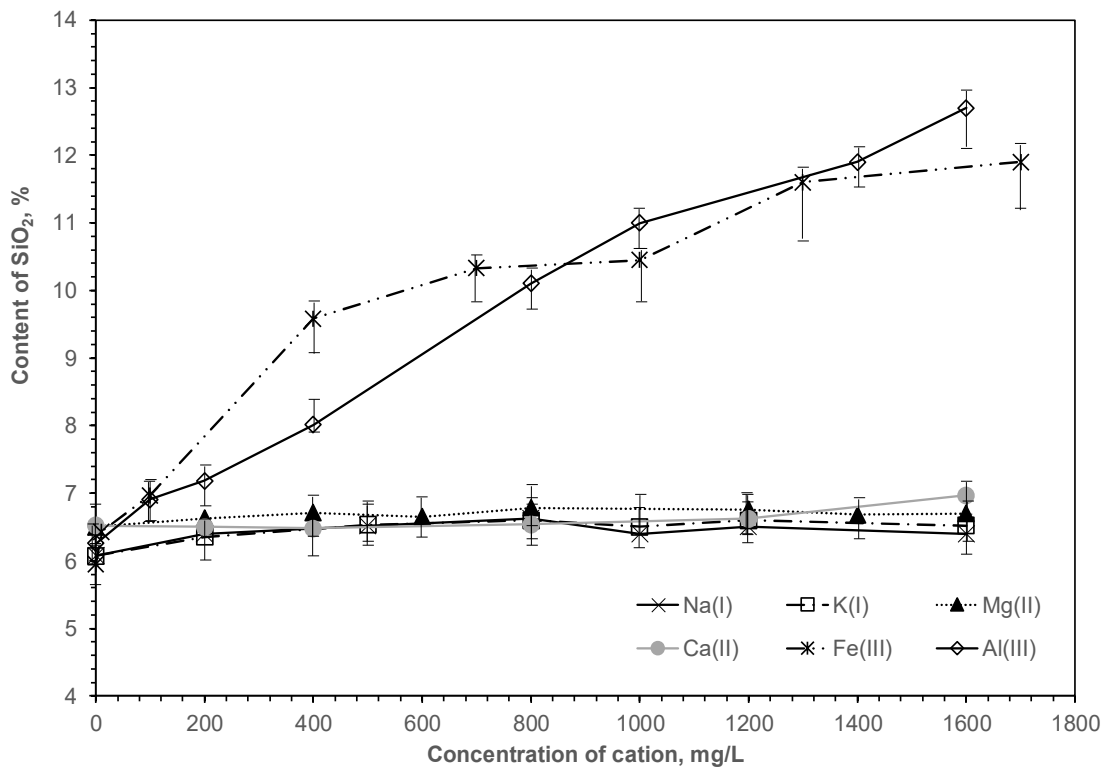

(c)

Figure 3. The effect on the recovery/grade of $\mathrm{Fe}$ and content of $\mathrm{SiO}_{2}$ in concentrate as a function of dosage of cation in the tap water: (a) Recovery of $\mathrm{Fe}$, (b) Grade of $\mathrm{Fe}$, and (c) Content of $\mathrm{SiO}_{2}$. 


\subsection{Flotation Recovery of Quartz in the Presence of Cation}

Figure 4 illustrates the changes on the recovery of pure quartz in the absence/presence of cation, $\mathrm{Ca}^{2+}, \mathrm{Mg}^{2+}, \mathrm{Al}^{3+}$ or $\mathrm{Fe}^{3+}$ ions at a concentration of $1 \mathrm{mmol} / \mathrm{L}$ as a function of $\mathrm{pH}$. The data indicate that the flotation recovery does not change a lot in the presence of $\mathrm{Ca}^{2+}$ or $\mathrm{Mg}^{2+}$ ions at a $\mathrm{pH}$ range of 2-8. But it was significantly influenced by the addition of $\mathrm{Al}^{3+}$ or $\mathrm{Fe}^{3+}$ ions. A severe drop by more than $80 \%$ or $50 \%$ on the recovery of quartz occurs at a $\mathrm{pH}$ of $7-9$ by adding $\mathrm{Al}^{3+}$ or $\mathrm{Fe}^{3+}$ ions, respectively. This is well in accordance with the results as shown in Figure 3, which show that at this pH range the flotation performance of the iron oxides was deteriorated with increasing the concentration of $\mathrm{Al}^{3+}$ or $\mathrm{Fe}^{3+}$ ions. According to the previous research performed by Araujo and Coelho (1991), it indicates that the quartz is greatly depressed at a $\mathrm{pH}$ range of 7-9 in the presence of $\mathrm{Al}^{3+}$ ions during amine flotation, which strongly depends on the adsorption density of $\mathrm{Al}^{3+}$ ions on the quartz [20].

Based on the data shown in Table 3, a large amount of $\mathrm{Al}^{3+}$ ions accumulated from the flotation process by using the recycled tailing water was not observed while a dramatic increase on the content of $\mathrm{TFe}^{\mathrm{n}+}$ ions occurred in the concentrate water. The built-up of $\mathrm{TFe}^{\mathrm{n}+}$ probably contributes to the unexpected entrainment of the silica into the concentrate, and inducing a substantial increase on the content of $\mathrm{SiO}_{2}$.

There is also a slight downward trend on the flotation recovery at a $\mathrm{pH}$ range of over 8 in the presence of $\mathrm{Ca}^{2+}$ or $\mathrm{Mg}^{2+}$ ions in comparison with the original one without any addition of cation at the same $\mathrm{pH}$ range. The decrease on the recovery of quartz is probably attributable to the hydrolyzed species of them at this range of $\mathrm{pH}$. A built-up of the total hardness, and content of $\mathrm{Ca}^{2+} / \mathrm{Mg}^{2+}$ ions as well, of course, cannot be ignored as shown in Table 3. But it does not seem to help the improvement on either the recovery of $\mathrm{Fe}$ or the content of $\mathrm{SiO}_{2}$ in the concentrate by using the recycled tailing in the process based on the results as shown in Figures 3 and 4.

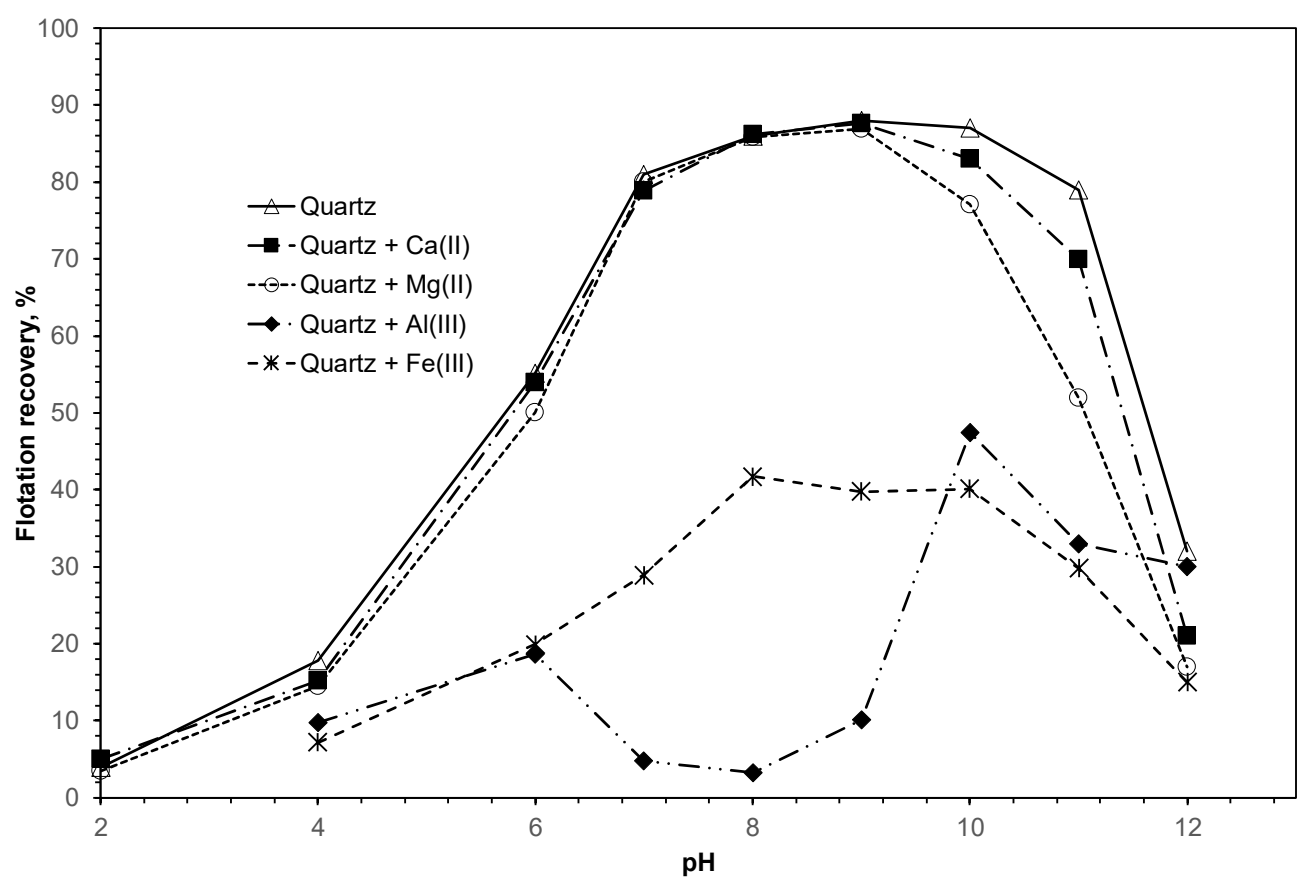

Figure 4. Flotation recovery of quartz in the absence/presence of $\mathrm{Ca}^{2+}, \mathrm{Mg}^{2+}, \mathrm{Al}^{3+}$ or $\mathrm{Fe}^{3+}$ ions at a concentration of $1 \mathrm{mmol} / \mathrm{L}$ as a function of $\mathrm{pH}$.

\subsection{Zeta Potentials of Quartz in the Presence of Cations}

The zeta potential values of the quartz mixed with $\mathrm{Ca}^{2+}, \mathrm{Mg}^{2+}, \mathrm{Fe}^{3+}$ or $\mathrm{Al}^{3+}$ ions as a function of $\mathrm{pH}$ were observed in Figure 5, indicating that there is a reversal of the surface charge at a $\mathrm{pH}$ range of approximately 2-8 when the quartz interacted with $\mathrm{Al}^{3+}$ or $\mathrm{Fe}^{3+}$ ions. It shows a reversal of the surface 
charge for the quartz treated with $\mathrm{Mg}^{2+}$ ions at a very strong alkali atmosphere, but no reversal at all for the quartz treated with $\mathrm{Ca}^{2+}$ ions at a $\mathrm{pH}$ range of 1-12. This is inconsistent with the results from Figure 4, which show that the surface adsorption of these metal ions/their complexes on quartz is strongly $\mathrm{pH}$ dependent. Since the difference in these isoelectric point (IEP) values is associated with differences in the surface complex formation at the mineral-liquid interfaces.

No reversal, but only the slightly less zeta potential on quartz occurs in the presence of $\mathrm{Ca}^{2+}$ ions, which is probably due to its low concentration based on the literature $[7,16-18]$. In terms of the $\mathrm{Ca}^{2+}$ species distribution diagram as shown in Figure 6, the predominant species in water are $\mathrm{Ca}^{2+}$ ions at a $\mathrm{pH}$ range of less than 10 , but $\mathrm{Ca}(\mathrm{OH})^{+}$, and $\mathrm{Ca}(\mathrm{OH})_{2(\mathrm{~s})}$ at a $\mathrm{pH}$ range of over 10 . This is well explained by the data as shown in Figure 4 . The precipitate of $\mathrm{Ca}(\mathrm{OH})_{2}$ partly contributes to the drop on flotation recovery of quartz at this $\mathrm{pH}$ due to hindering the interaction of the amine collector on mineral surfaces while the disturbance of $\mathrm{Ca}^{2+}$ ions on mineral surfaces at a $\mathrm{pH}$ range of less than 10 is possibly relevant to the layer structure of the silica and its exchange rate with $\mathrm{NH}_{3}{ }^{+}$[21].

In terms of the $\mathrm{Al}^{3+}, \mathrm{Fe}^{3+}$ species distribution diagram as shown in Figure 6, at $\mathrm{pH}$ 8.5-9.5 the predominant species in water are $\mathrm{FeOH}^{2+}, \mathrm{Fe}(\mathrm{OH})^{2+}$, and $\mathrm{Fe}(\mathrm{OH})_{3}$ for $\mathrm{Fe}^{3+}$ ions, or $\mathrm{Al}(\mathrm{OH})_{3}, \mathrm{Al}(\mathrm{OH})^{2+}$, and $\mathrm{Al}(\mathrm{OH})^{4-}$ for $\mathrm{Al}^{3+}$ ions. The formation of these species on the quartz probably contributes to its less negative zeta potential, compared with the ones without the addition of any cation. The precipitate of $\mathrm{Fe}(\mathrm{OH})_{3}$ or $\mathrm{Al}(\mathrm{OH})_{3}$ on the quartz may also act as metal oxide coating disturbs the interaction with the amine collector. This is well in agreement with the data from Figure 2, which demonstrate that the enrichment of the cations, especially $\mathrm{Al}^{3+}$ or $\mathrm{Fe}^{3+}$ ions in the recycled process water, contributes to the increase in the content of $\mathrm{SiO}_{2}$ in concentrates with increasing the percent of the recycled tailing water used in the flotation. Based on the previous literature [7,22-25], the possible competitive adsorption mechanism of those cations on the silica in the reverse cationic flotation of the iron oxides at weak alkali $\mathrm{pH}$ may involve the specific $\mathrm{pH}$-dependence of the metal binding and surface complexes interactions shown as follows (Modified from Fuerstenau et al. (1963) and Stumm (1992) [7,25]), in the water:

$$
\begin{gathered}
\mathrm{Fe}\left(\mathrm{H}_{2} \mathrm{O}\right)_{6}^{3+} \leftrightarrow \mathrm{Fe}\left(\mathrm{H}_{2} \mathrm{O}\right)_{5} \mathrm{OH}^{2+}+\mathrm{H}^{+} \\
\mathrm{Fe}\left(\mathrm{H}_{2} \mathrm{O}\right)_{5} \mathrm{OH}^{2+} \leftrightarrow \mathrm{Fe}\left(\mathrm{H}_{2} \mathrm{O}\right)_{4}(\mathrm{OH})_{2}^{+}+\mathrm{H}^{+} \\
\mathrm{Fe}\left(\mathrm{H}_{2} \mathrm{O}\right)_{4}(\mathrm{OH})_{2}^{+} \leftrightarrow \mathrm{Fe}\left(\mathrm{H}_{2} \mathrm{O}\right)_{3}(\mathrm{OH})_{3}+\mathrm{H}^{+} \\
\leftrightarrow \mathrm{Fe}(\mathrm{OH})_{3}+3 \mathrm{H}_{2} \mathrm{O}+\mathrm{H}^{+}
\end{gathered}
$$

on the surface of quartz:

$$
\begin{aligned}
& >\mathrm{Si}-\mathrm{OH}+\mathrm{Fe}\left(\mathrm{H}_{2} \mathrm{O}\right)_{6}^{3+} \leftrightarrow>\mathrm{Si}-\mathrm{OFe}\left(\mathrm{H}_{2} \mathrm{O}\right)_{5} \mathrm{OH}^{+}+2 \mathrm{H}^{+} \\
> & \mathrm{Si}-\mathrm{OH}+\mathrm{Fe}\left(\mathrm{H}_{2} \mathrm{O}\right)_{5} \mathrm{OH}^{2+} \leftrightarrow>\mathrm{Si}-\mathrm{OFe}\left(\mathrm{H}_{2} \mathrm{O}\right)_{4} \mathrm{OH}+2 \mathrm{H}^{+} \\
> & \mathrm{Si}-\mathrm{OH}+\mathrm{Fe}\left(\mathrm{H}_{2} \mathrm{O}\right)_{4}(\mathrm{OH})_{2}^{+} \leftrightarrow>\mathrm{Si}-\mathrm{OFe}\left(\mathrm{H}_{2} \mathrm{O}\right)_{3} \mathrm{OH}+\mathrm{H}^{+}
\end{aligned}
$$

The species after the adsorption of the cations on the minerals can modify the surface potentials and substantially influence the electrostatic adsorption between minerals and DDA [7,14-19]. 


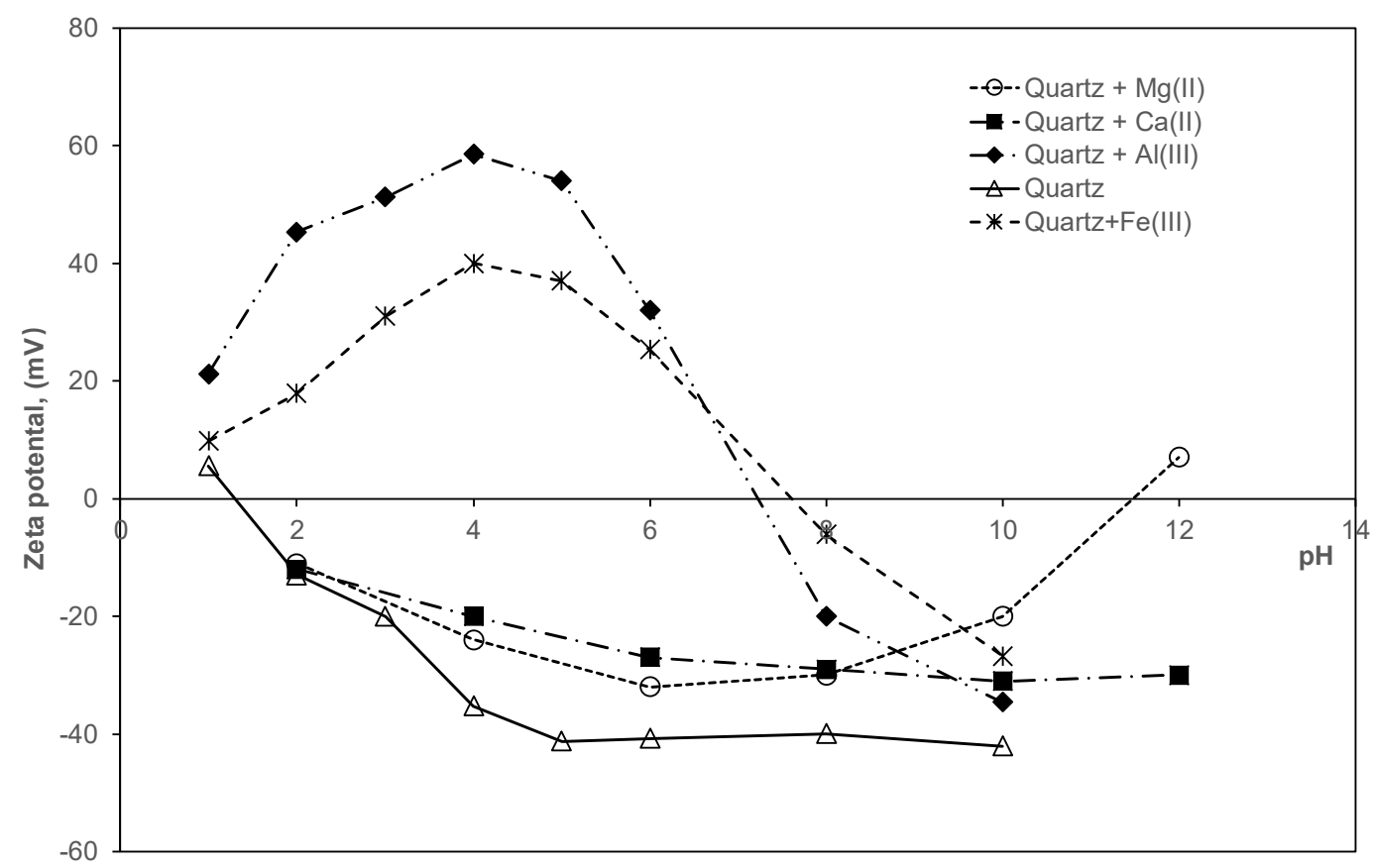

Figure 5. Zeta potentials of the quartz absorbed with $\mathrm{Ca}^{2+}, \mathrm{Mg}^{2+}, \mathrm{Al}^{3+}$ or $\mathrm{Fe}^{3+}$ at a concentration of $1.5 \times 10^{-3} \mathrm{~mol} / \mathrm{L}$.

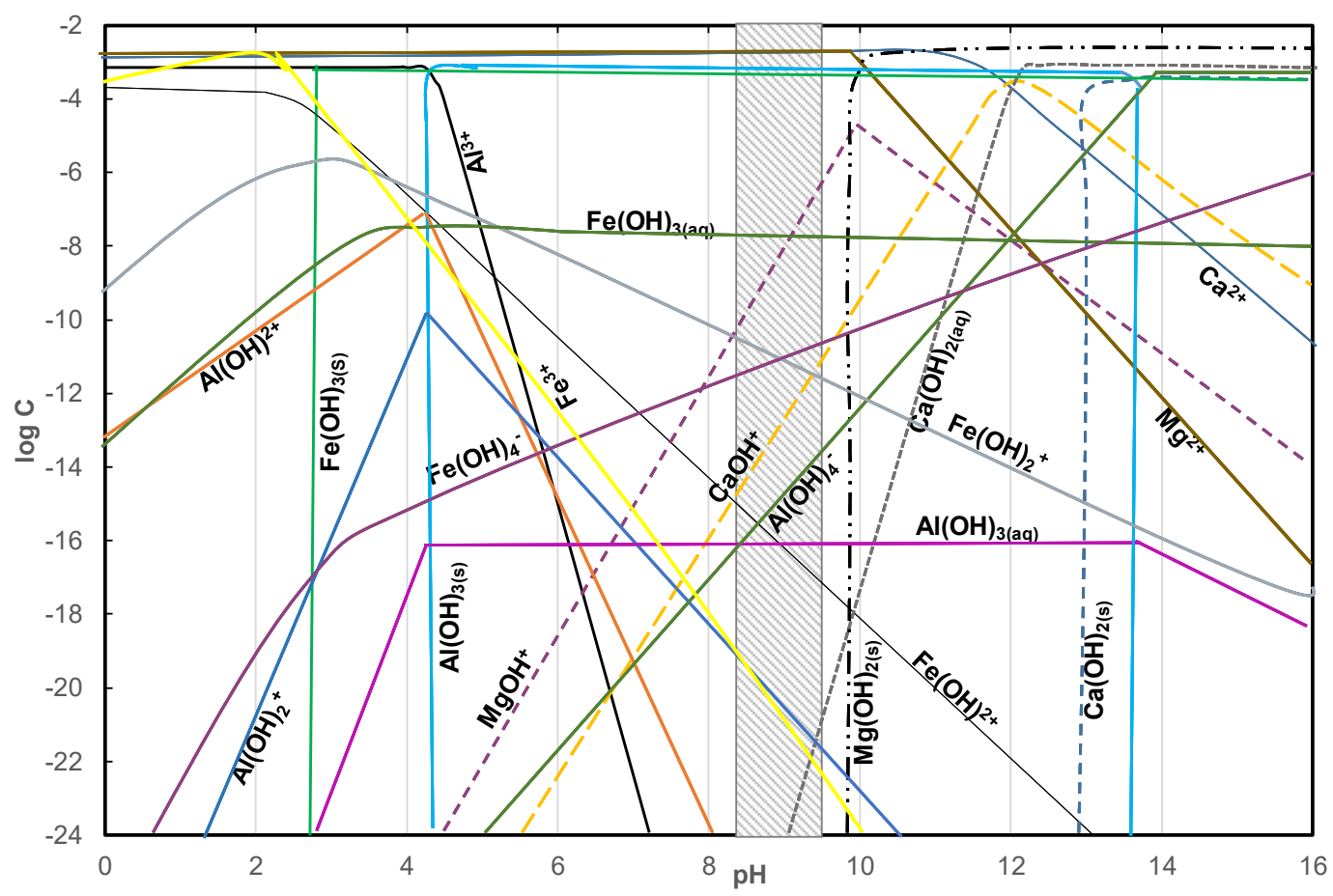

Figure 6. $\log \mathrm{C}-\mathrm{pH}$ curve of $\mathrm{Ca}^{2+}, \mathrm{Mg}^{2+}, \mathrm{Fe}^{3+}$ or $\mathrm{Al}^{3+}$ at a concentration of $1.5 \times 10^{-3} \mathrm{~mol} / \mathrm{Lin}$ the distilled water (Modified from Ruan et al., 2008; Ren et al. 2018) [4,26].

\subsection{Effect on Flotation Performance in the Presence of $\mathrm{Cl}^{-}$or $\mathrm{SO}_{4}{ }^{2-}$}

The content of $\mathrm{Cl}^{-}$or $\mathrm{SO}_{4}{ }^{2-}$ in the recycled tailing water is much higher than in the tap water as shown in Table 3. The influence of these anions on the flotation behavior was presented in Figure 7. It shows that $\mathrm{Cl}^{-}$ions have less influence on the recovery of the iron oxides than $\mathrm{SO}_{4}{ }^{2-}$ ions. At a concentration of $\mathrm{Na}_{2} \mathrm{SO}_{4}(1500 \mathrm{mg} / \mathrm{L})$, a concentrate at a grade of $60.1 \% \mathrm{Fe}$ and $5.7 \% \mathrm{SiO}_{2}$ with a recovery of $83.4 \% \mathrm{Fe}$ was harvested. The data indicate that it is beneficial to enhance the recovery of 
the iron oxides in the presence of $\mathrm{SO}_{4}{ }^{2-}$. According to the previous research reported by Ahmed and Masimov (1968) and Hesleitner et al. (1987), residual chloride ion can adsorb to the iron oxide surfaces, therefore lowering its IEP by the formation of a positively charged chlorocomplex $[27,28]$. Wantanabe and Seto (1986) also found that the adsorption of sulfate ions can lower the IEP of iron oxides [29]. The schematic surface complex structure of the hydrous iron oxide surface in the presence of $\mathrm{Cl}^{-}$and $\mathrm{SO}_{4}{ }^{2-}$ ions was shown in Figure 8, which indicates that $\mathrm{Cl}^{-}$ions are considered to adsorb mainly in outer-sphere complexes and as diffuse ion swarm while $\mathrm{SO}_{4}{ }^{2-}$ ions are more likely to form inner and outer sphere binuclear or polynuclear surface complexes on hematite at near-neutral $\mathrm{pH}$ values [24,29]. They can provide less suitable leaving groups for detachment into the water, therefore successfully inhibiting the dissolution of iron ions from the mineral surfaces [30-33]. The coordination of this anion with a multi-valent cation from the pulp, of course, needs to be considered as well.

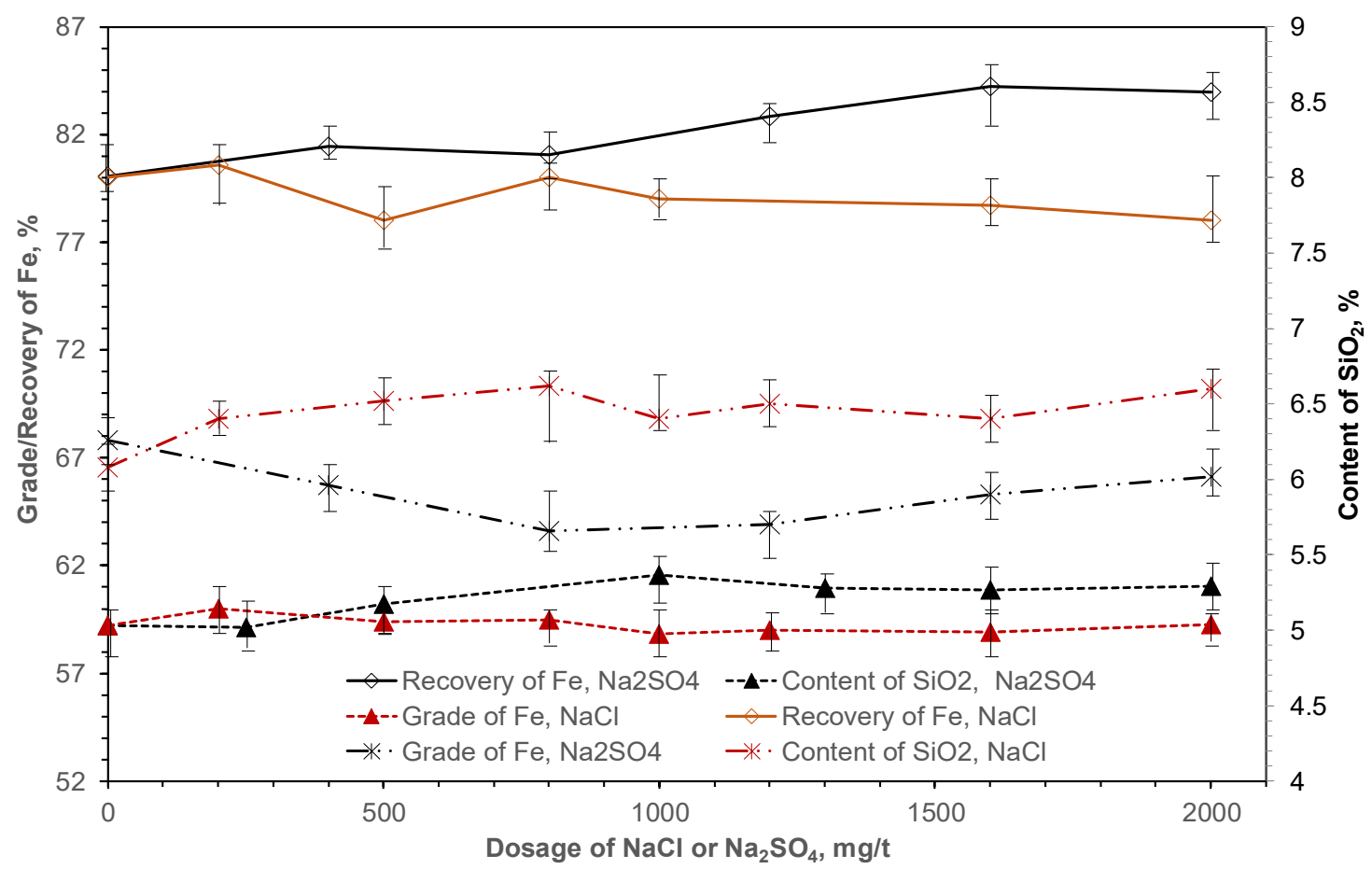

Figure 7. The effect on the recovery/grade of $\mathrm{Fe}$ and content of $\mathrm{SiO}_{2}$ in concentrate as a function of dosage of $\mathrm{Cl}^{-}$or $\mathrm{SO}_{4}{ }^{2-}$ ions in the tap water.

It is worthwhile to note that the content of $\mathrm{SO}_{4}{ }^{2-}$ ions as shown in Table 3 was dramatically built up by approximately 2 times in the concentrate water, compared with the one in the feed if the recycled tailing water was fully introduced into the entire flotation process. The formation of both outer-sphere inner and outer sphere binuclear or polynuclear surface complexes of sulfate ions on iron oxides may attribute to it. The less presence of the cations with high valency in the pulp, for instance, $\mathrm{Fe}^{3+}$ ions, due to either the inhabited dissolution from the surface of the minerals or coordination of sulfate ions in the pulp, responsibly enhance the selectivity of the cationic reverse flotation, which is well in accordance with the flotation results as shown in Figures 2-4. However, the influences of these cations discussed have been considered independently of each other. In the flotation process, those cations can influence simultaneously, and the extent of their impact can be largely different. 


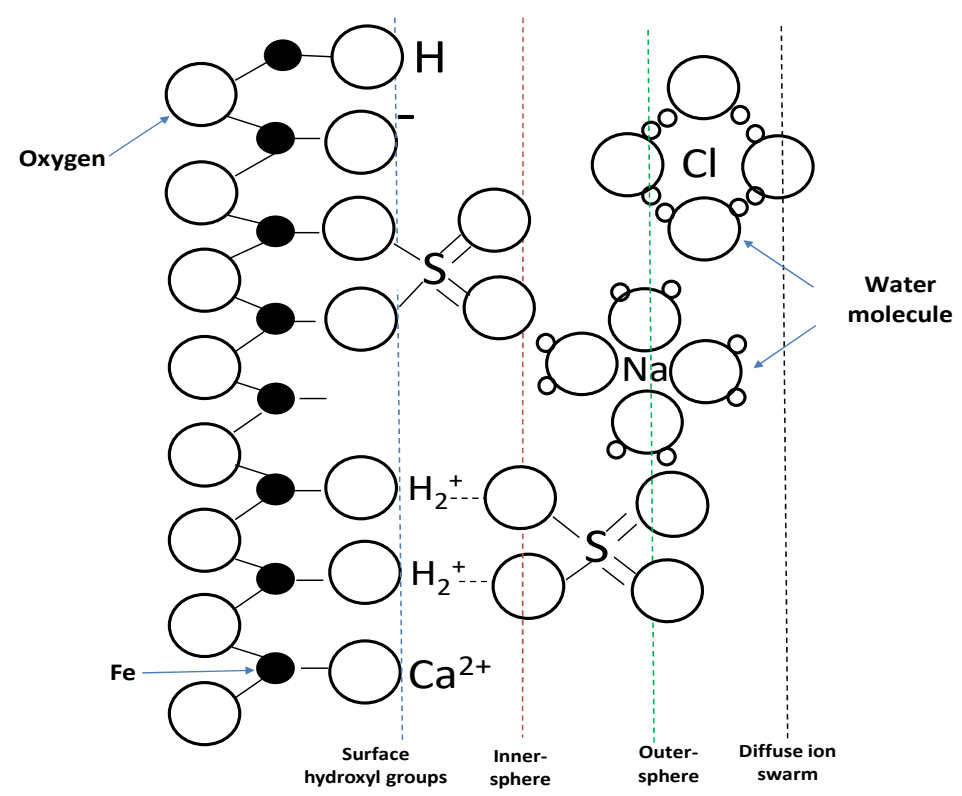

Figure 8. A schematic surface complex structure of the hydrous iron oxide surface, showing planes associated with surface hydroxyl groups, inner-sphere complexes, outer-sphere complexes, and the diffuse ion swarm (Modified from Stumm (1995) [25]).

\section{Conclusions}

The flotation results pointed out that the presence of multi-valent cation, $\mathrm{Fe}^{3+}, \mathrm{Al}^{3+}, \mathrm{Ca}^{2+}, \mathrm{or} \mathrm{Mg}^{2+}$, tends to have more significant influences on the selectivity of the flotation than mono-valent cation, $\mathrm{Na}^{+}$or $\mathrm{K}^{+}$. A sharp increase by $1.5 \%$ on the content of $\mathrm{SiO}_{2}$ in concentrate, coupled with an increase of $6.0 \%$ recovery of $\mathrm{Fe}$, was also observed by using the recycled tailing water only in comparison by using fresh tap water only. A build-up of the cations, especially $\mathrm{TFe}^{\mathrm{n}+}, \mathrm{Ca}^{2+}$ or $\mathrm{Mg}^{2+}$, in the recycled process water contributes to it. But $\mathrm{SO}_{4}{ }^{2-}$ ions seem to have a more positive effect on the recovery of iron oxides than $\mathrm{Cl}^{-}$ions. This is probably due to the formation of the inner and outer sphere binuclear or polynuclear surface complexes on mineral surfaces at near-neutral $\mathrm{pH}$ values, providing less suitable leaving groups for detachment into the water, therefore successfully inhibiting the dissolution of metal ions with high valence. It can also coordinate the dissolved cations in the pulp and lower the effect of these cations in the flotation.

Author Contributions: M.T. and S.W. contributed to the idea of this project. M.T. designed and performed all tests, interpretation of data, etc.

Funding: This research was funded by Natural Science Foundation of Yunnan Province (No. 2013FB021), Natural Science Foundation of Ministry of education (No. KKQA20142001).

Conflicts of Interest: The authors declare no conflict of interest

\section{References}

1. Muzenda, E. An investigation into the effect of water quality on flotation performance. Int. J. Chem. Mol. Nucl. Mater. Metal. Eng. 2010, 4, 562-566.

2. Michaux, B.; Rudolph, M.; Reuter, M.A. Challenges in predicting the role of water chemistry in flotation through simulation with an emphasis on the influence of electrolytes. Miner. Eng. 2018, 125, 252-264. [CrossRef]

3. Haselhuhn, H.J.; Carlson, J.J.; Kawatra, S.K. Water chemistry analysis of an industrial selective flocculation dispersion hematite ore concentrator plant. Int. J. Miner. Process. 2012, 102, 99-106. [CrossRef]

4. Ruan, Y.; Zhang, Z.; Luo, H.; Xiao, C.; Zhou, F.; Chi, R. Effects of metal ions on the flotation of apatite, dolomite and quartz. Minerals 2018, 8, 141. [CrossRef] 
5. Ren, L.; Qiu, H.; Zhang, Y.; Nguyen, A.; Zhang, M.; Wei, P.; Long, Q. Effects of alkyl ether amine and calcium ions on fine quartz flotation and its guidance for upgrading vanadium from stone coal. Powder Technol. 2018, 338, 180-189. [CrossRef]

6. Dove, P.M. The dissolution kinetics of quartz in aqueous mixed cation solutions. Geochim. Cosmochim. Acta 1999, 63, 3715-3727. [CrossRef]

7. Fuerstenau, M.C.; Palmer, B.R. Anionic Flotation of Oxides and Silicates; Society of Mining Engineers of AIME, Mineral Processing Division, Gaudin, A.M., Fuerstenau, M.C., Eds.; American Institute of Mining, Metallurgical, and Petroleum Engineers: New York, NY, USA, 1976; pp. 148-196.

8. Nevasaia, D.; Guerrero-Ruiz, A.; Lopez-Gonzalez, J.D.D. Adsorption of polyoxyethylenic nonionic and anionic surfactants from aqueous solution: Effects induced by the addition of $\mathrm{NaCl}$ and $\mathrm{CaCl}_{2}$. J. Colloid Interface Sci. 1998, 205, 97-105. [CrossRef]

9. Fuerstenau, M.C.; Martin, C.C.; Bhappu, R.B. The Role of Hydrolysis in Sulfonate Flotation of Quartz. Trans. AIME 1963, 226, 449-454.

10. Chen, Y.; Tong, X.; Feng, X.; Xie, X. Effect of Al(III) ions on the separation of cassiterite and clinochlore through reverse flotation. Minerals 2018, 8, 347. [CrossRef]

11. Durate, R.S.; Lima, R.M.F.; Leao, V.A. Effect of inorganic and organic depressants on the cationic flotation and surface charge of rhodonite-rhodochrosite. Rem Revista Escola de Minas 2015, 68, 463-469. [CrossRef]

12. Flood, C.; Cosgrove, T.; Howell, I.; Revell, P. Effects of electrolytes on adsorped polymer layers: Poly(ethylene oxide)—Silica system. Langmuir 2006, 22, 6923-6930. [CrossRef] [PubMed]

13. Ofor, O. Effect of inorganic ions on oleate adsorption at a Nigerian hematite-Water interface. J. Colloid Interface Sci. 1996, 179, 323-328. [CrossRef]

14. Choi, J.; Choi, S.; Park, K.; Han, Y.; Kim, H. Flotation behaviour of malachite in mono-and di-valent salt solutions using sodium oleate as a collector. Int. J. Miner. Process. 2016, 146, 38-45. [CrossRef]

15. Wang, J.; Xie, L.; Liu, Q.; Zeng, H. Effects of salinity on xanthate adsorption on sphalerite and bubble-sphalerite interactions. Miner. Eng. 2015, 77, 34-41. [CrossRef]

16. Brown, P.L.; Ekberg, C. Alkaline Earth Metals, Hydrolysis of Metal Ions; Wiley-VCH Verlag GmbH \& Co. KGaA: Weinheim, Germany, 2016; pp. 155-224.

17. Rao, S.R. Electrical characteristics at interfaces. In Surface Chemistry of Froth Flotation, 2nd ed.; Kluwer Academic/Plenum Publishers: New York, NY, USA, 2004; pp. 209-256.

18. Shortridge, P.G.; Harris, P.J.; Bradshaw, D.J. The influence of ions on the effectiveness of polysaccharide depressants in the flotation of talc. In Proceedings of the 3rd UBC-McGill Bi-Annual International Symposium on Fundamentals of Mineral Processing, Canadian Institute of Mining, Metallurgy and Petroleum, Quebec City, QC, Canada, 20-26 August 1999; pp. 155-169.

19. Ikumapayi, F.; Makitalo, M.; Johansson, B.; Rao, K.H. Recycling of process water in sulphide flotation: Effect of calcium and sulphate ions on flotation of galena. Miner. Eng. 2012, 39, 77-88. [CrossRef]

20. De Araujo, A.C.; Coelho, E.M. Effect of aluminum aqueous species on the amine flotation of quartz. Trans. ASME 1991, 290, 1930-1934.

21. Chen, Z.; Ren, Z.; Gao, H.; Lu, J.; Jin, J.; Min, F. The Effects of Calcium Ions on the Flotation of Sillimanite Using Dodecylammonium Chloride. Minerals 2017, 7, 28. [CrossRef]

22. Rusch, B.; Hanna, K.; Humbert, B. Coating of quartz silica with iron oxides: Characterization and surface reactivity of iron coating phases. Colloid Surf. A 2010, 353, 172-180. [CrossRef]

23. Rao, S.R.; Espinosa-Gomez, R.; Finch, J.A.; Biss, R. Effects of water chemistry on the flotation of pyrochlore and silicate minerals. Miner. Eng. 1988, 1, 189-202. [CrossRef]

24. Stumm, W. The Inner-sphere surface complex-A key to understanding surface reactivity. In Aquatic Chemistry; American Chemistry Society: Washington, DC, USA, 1995; pp. 1-32.

25. Stumm, W. The coordination chemistry of the hydrous oxide-water interface. In Chemistry of Solid-Water Interface, 1st ed.; Wiley-Interscience: Hoboken, NJ, USA, 1992; Chapter 2; pp. 13-41.

26. Ren, L.; Qiu, H.; Qin, W.; Zhang, M.; Li, Y.; Wei, P. Inhibition mechanism of $\mathrm{Ca}^{2+}, \mathrm{Mg}^{2+}$ and $\mathrm{Fe}^{3+}$ in fine cassiterite flotation using octanohydroxamic acid. R. Soc. Open Sci. 2018, 5, 180158. [CrossRef] [PubMed]

27. Ahmed, S.M.; Maksimov, D. Studies of the double layer cassiterite and rutile. J. Colloid Interface Sci. 1968, 29, 97-104. [CrossRef]

28. Hesleitner, P.; Babic, D.; Nikola, K.; Matjevic, E. Adsorption at sold/solution interfaces. 3. Surface charge and potential of colloidal hematite. Langmuir 1987, 3, 983-990. [CrossRef] 
29. Wantanaba, H.; Seto, J. The point of zero charge and the isoelectric point of $\alpha-\mathrm{Fe}_{2} \mathrm{O}_{3}$ and $\gamma-\mathrm{Fe}_{2} \mathrm{O}_{3}$. Bull. Chem. Soc. Jpn. 1986, 59, 2683-2687.

30. Westall, J. Adsorption Mechanisms in Aquatic Chemistry. In Aquatic Surface Chemistry; Stumm, W., Ed.; John Wiley: New York, NY, USA, 1987; pp. 3-32.

31. Hug, S.J. In situ Fourier transform infrared measurements of sulfate adsorption on hematite in aqueous solutions. J. Colloid Interface Sci. 1997, 188, 415-422. [CrossRef]

32. Peak, D.; Ford, R.G.; Sparks, D.L. An in-situ ATR-FTIR investigation of sulfate bonding mechanisms on goethite. J. Colloid Interface Sci. 1999, 218, 289-299. [CrossRef] [PubMed]

33. Wijnja, H.; Schulthess, C.P. Vibrational spectroscopy study of selenate and sulfate adsorption mechanisms on Fe and Al (hydr)oxide surfaces. J. Colloid Interface Sci. 2000, 229, 286-297. [CrossRef] [PubMed]

C 2019 by the authors. Licensee MDPI, Basel, Switzerland. This article is an open access article distributed under the terms and conditions of the Creative Commons Attribution (CC BY) license (http://creativecommons.org/licenses/by/4.0/). 